\title{
Edebiyat Diplomasisi: Türkiye'de Kamu Diplomasisi Aracı Olarak Edebiyat
}

Geliş Tarihi/Received: 28.02.2021 Kabul Tarihi/Accepted: 09.07.2021 DOI: 10.46372 /arts.888247

\author{
Mehmet Özkan YILDIRIM \\ Marmara Üniversitesi, SBE \\ Illetişim Bilimleri Doktora Programı \\ mehmetozkanyildirim@gmail.com \\ ORCID: 0000-0003-3343-1950
}

\begin{abstract}
öz
Günümüzde devletlerin dış politika hedeflerini etkili bir şekilde savunabilmeleri, kamuoyunun ve hedef kitlelerinin yanında hedef kitlelerinin iletişimde olduğu çevreyi ne ölçüde etkilediğiyle yakından ilişkilidir. Bu anlamda karşılıklı müzakere ve iletişimin önemiyle birlikte sadece devletlerin değil, halkların da hedef kitle seçildiği ve ona göre stratejiler geliştirildiği kamu diplomasisi faaliyetleri, uzun vadede barışa hizmet ederek, güven tesis etmenin ön koşulu olarak karşımıza çıkmaktadır. Dolayısıyla, bu faaliyetlerde kültürel alandan gündelik hayata değin pek çok pratikler dizisi önemli bir rol oynar. Bu çalışmanın amacı, edebiyatın kamu diplomasisiyle ilişkisini güncel örnekler bağlamında araştırmak, çeviri faaliyetlerinden edebiyat festivallerine değin incelemektir. Yumuşak güç kullanılarak icra edilen kamu diplomasisinin yaygın bir kullanım alanı bulduğu kültürel faaliyetler içerisinde yer alan edebiyat metinleri, edebiyat festivalleri, ülkelerin kültürel mirasını, insan olma hallerini diğer ülkelerin insanlarına tanıtmak ve etkileşim haline geçmek için mühim bir alanı teşkil etmektedir. Kültürel diplomasi sonrası ele alınacak edebiyat diplomasisi kavramı açıklanarak, bunun Türkiye'de hangi örnekler bağlamında ele alınabileceğini tartışacak olan çalışmada, tarihsel ve güncel örnekler üzerinden edebiyatın bir kamu diplomasisi aracı olarak kullanılması, edebiyatın ilişki inşası işlevi ve evrensel bir barış aracı olarak konumu irdelenmeye çalışılacaktır. Araştırmada özel olarak kamu diplomasisi ve edebiyatın kesişen, birbirini destekleyen noktaları ve kullanım alanları serimlenmiş, hangi faaliyetlerin gerçekleştirildiği gösterilmeye çalışılmıştır.
\end{abstract}

Anahtar Kelimeler: edebiyat, kamu diplomasisi, edebiyat diplomasisi, yumuşak güç, kültürel diplomasi

Yıldırım, M. (2021). Edebiyat Diplomasisi: Türkiye'de

Kamu Diplomasisi Aracı Olarak Edebiyat. ARTS:

Artuklu Sanat ve Beşeri Bilimler Dergisi, 6, 14-40 


\title{
Literary Diplomacy: Literature as a Tool of Public Diplomacy in Turkey
}

\begin{abstract}
This work aims to study the relation of literature to public diplomacy within representative contexts and to investigate it from translation activities to literature festivals. Literary texts and literature festivals as part of cultural activities, in which public diplomacy conducted by means of soft power finds a wide field of use, constitute a significant medium to acquaint people of other nations with the cultural heritage and human nature of nations. In this work, following a discussion on cultural diplomacy, the concept of literary diplomacy will be explained and the potential of its utilization in Turkey in regards to various examples will be studied through literature survey. Furthermore, the implementation of literature as a tool of public diplomacy via historical and contemporary examples will be presented. Concluding remarks will be made on literature's function of relationship building and its position as an agent of universal peace. In particular, points where public diplomacy and literature intersect and enhance each other and their scopes of application will be laid out in this work.
\end{abstract}

Keywords: literature, public diplomacy, literary diplomacy, soft power, cultural diplomacy 


\section{arts}

\section{Gíriş'}

Tarafların ve karşılıklı çıkarın insan ilişkilerinin temel dinamiklerini oluşturduğunu, böylesi durumların yaşandığı bir yerde karşııklı iletişimin, diyaloğun bir ihtiyaç haline geldiğini tarihsel olarak yaşanan deneyimlere baktığımızda açıkça görürüz. Zira insan ilişkilerinden doğan sağduyu ve diyalog ihtiyacı devletlerin varlığını sürdürmesinde, iç ve dış politika hedeflerine ulaşmasında önem teşkil eder. Diyaloğu ve müzakereyi devletlerin resmi temsilciler eliyle yürütmesi doğal olarak diplomasi kavramını görünür kılar. Devletler arasında yaşanan krizlerde, sorunlarda karşılıklı müzakereyi ön plana çıkaran diplomasi kavramı, kullanım alanı bulduğu yerlerde daha çok barışı sürdürmenin ve barış içinde yaşamanın anahtarı, politikaların yaşam alanı bulması için başvurulan bir araç, bir taktik şeklinde karşımıza çıkar. Sürekli değişime uğrayan dünya düzeni diplomasiyi ve sağduyuyu devletlerarası ilişkilerde bir zorunluluk haline getirmiş, çeşitli değişiklikleri görünür kılmıştır. İhtiyacı zorunluluğa dönüştüren dünya düzeni diplomasinin yaşam alanı bulduğu kimi yerleri ve diplomasiyi dönüşüme tabi tutarak onu yalnızca devletlerin tekelinden çıkarmıştır.

Sürekli değişim geçiren dünya düzeni, eski araçları geride bıraktığı gibi yeni hedeflere eski araçlarla ulaşılamayacağını da göstermiştir. Dolayısıyla yeni davranış ve sorunlarla baş etme hallerini de beraberinde getirmiş̧ir. Illk olarak 1960' larda varlık alanı bulup bir süre sonra sönümlenen, daha sonra ise 2000'li yılların başlarında önemi tekrar açığa çıkan kamu diplomasisi kavramının uygulama alanının ve aktörlerinin çeşitliliği intiyaçlara karşılık vermeye, değişen dünya düzenine ayak uydurmaya başlamıştır. Böylece diplomasi yalnızca devletlerarasında değil, devletleri ve başka devletlerin halklarını da ilgilenilmesi gereken bir özne topluluğu olarak tarih sahnesine çıkarmıştır. Daha sonra gelişerek sivil toplumun ve halkların kullandığı bir araç olan kamu diplomasisi, sert güce başvurmadan yumuşak güç kullanılarak icra edilir. Sempati ve karşılıklı anlayış doğuran yumuşak güç, politikaların uzun dönemli uygulanmasında, kalıcı sonuçlar elde edilebilmesi noktalarında barışçı bir yol izlemeye; ulusları, uluslararası kurumları sahip olduğu değerleri ön plana çıkarmaya ve bir değer üretmeye sevk etmiştir.

Karşılıkı anlayışın, diyaloğun, bilgilendirmenin ön plana çıktığı kamu diplomasisi kavramı pek çok alanda uygulanmakta, ikna ve sempati uyandırmanın başat aracı konumunda varlık alanı bulmaktadır. Yumuşak gücü yüzeye çıkaran

\footnotetext{
1 Bu çalışma, 18 Aralık 2019 tarihinde Galatasaray Üniversitesi'nde gerçekleştirilen Stratejik iletişim Yönetimi Konferansları (GSÜStrat) II: "Yeni Kamu Diplomasisi: Diyalog ve Iliş̧ki İnşa Ełme" başlıklı ulusal konferansta sunulan ancak yayımlanmayan metnin gözden geçirilmiş ve yeniden yazılmış halidir.
} 
uygulama alanlarına baktığımızda kültür, eğitim, spor, teknoloji gibi alanlara rastlarız. Bu alanlarda uluslar çekicilik oluşturabilir, bilgilendirmeyi, kendini anlatmayı, ikna sürecini olumlu sonuçlandırmayı başarabilir. Yumuşak güç kavramını ortaya atan düşünürlerden Joseph Nye (2008), kültürel faaliyetleri tanıtmanın, mevcut değerlerle cazibe yaratmanın ilişki inşasını kolaylaştırdığını, bu yönüyle diyaloğa imkân tanıdığını vurgular. Kültürel faaliyetler içerisinde değerlendirilen edebiyat metinleri ve bileşenleri ilişki inşasında önemli bir yerde durur, düşünce düzeyinde bir farkındalık ve imaj yaratarak ulusları ve kültürünü başka uluslara taşır.

Bu anlamıyla çalışmada, öncelikle diplomasi kavramı açıklanarak zuhur ettiği noktalar vurgulanacak, böylece geleneksel diplomasiden kamu diplomasisine geçiş netleştirilecektir. Ardından kamu diplomasisinin uygulama alanlarının çeşitliliğinden yola çıkarak kültürel diplomasi kavramı üzerinde durulacak, kültürün bileşenleri, kültürel diplomasisinin aktörleri irdelenecektir. Son olarak edebiyat diplomasisi başlığı altında edebiyat ve kamu diplomasisinin kesişen noktaları, birbirlerini destekleyecek, kamu diplomasisi aktörlerini iç ve dış politika hedeflerinde başarıya ulaştıracak durumları kimi güncel ve tarihsel örneklerle açıklamaya gayret edilecektir. Diplomasi ve edebiyat alanlarındaki literatürden faydalanarak çalışmada edebiyat ve diplomasi ilişkisi irdelenmeye çalışılacaktır.

\section{DIPLOMASi}

Devletler, uluslararası platformlarda varlığını ortaya koyabilmek, çıkarlarını korumak, devletlerarası ilişkilerini sürdürmek için çeşitli taktik ve stratejiler uygularlar. Bu amaçla, tarihi çok eskiye dayanan bir kavram olmakla birlikte silahlı savaşın dışında, karşılıklı anlayıştan ve diyalojik bir zeminden zuhur eden, önemli bir dış politika aracı olarak karşımıza diplomasi kavramı çıkar. Sözcük olarak çok eski değilse de uygulama alanı açısından, kurum olarak varlığı uygarlığın başlarına hatta tarih öncesi dönemlere dayandırılır (Tuncer, 1994, s. 4). Kavramı uluslararası ilişkiler literatürüne kazandıran Edmund Burke ise kavramı devletlerarası politikaların uygulanmasında, yürütülmesinde beceri ve taktiğin ön plana çıkması anlamında kullanır (aktaran Kınlı, 2006, s. 60). Nicolson' a göre "müzakereler yoluyla uluslararası ilişkilerin yönetimi" (1963, s. 15), Tuch'a göre hükümetlerin uluslararası kamuoyunca yürüttükleri ve kültürleri yahut politikaları hakkında anlayış oluşturmaya çalıştıkları iletişim süreci (1990, s. 3) olarak tanımlanmıştır. Tarihsel olarak diplomasi aktörlerini ele 


\section{arts}

aldığımızda modern öncesi dünyada farklı devletlerarasındaki ilişkilerin resmi elçilik kanalları ve uluslararası dini liderler, hükümdarlar ve onların temsilcileri aracılığıyla gerçekleştiğini görürüz (Holden vd., 2007, s. 2).

Dış politika ile birlikte kullanılan diplomasi kavramı, politika değil politikanın yaşam alanı bulması, uygulanabilmesi için kullanılan bir araç, bir yürütme biçimi, politikaların uygulanmasını sağlayan bir taktik şeklinde değerlendirilebilir. Birbiriyle kesiştiği gibi birbirini tamamlayan, bir tamlık meydana getiren iki kavram şeklinde ele alınabilir. Uygulama alanı bulduğu ilk dönemlerde tek taraflı, kaynağın baskın olduğu bir iletişim biçimi söz konusuyken değişen dünya düzeniyle birlikte yeni biçimler edinmiş, farklı tamlayanlar eklemlenmiştir: Sessiz diplomasi, konferans diplomasi, ikili diplomasi, zirve diplomasisi vb.

Süreçler, uygulandığı dönemin koşullarına özgü olarak bir değişim geçirmiştir. Bugün ansiklopedi ve sözlüklere bakarak bu zamansal ve anlamsal farklııkları görebilmek mümkündür. Ancak genellikle karşımıza müzakere ve barış süreçlerinde barışçıl bir yol izleme gibi temel izlekler çıkar. Diğer yandan bu duruma olumsuz yaklaşan, kavrama farklı yerlerden bakan 'yalan söylemek ve inkâr etmek' noktalarından hareket ederek tanımlayan düşünürler, diplomatlar da söz konusudur (İskit, 2007, s. 14). Kavramın bu şekilde genişleme alanı bulması politikaların uygulanma biçimlerinden, mevcut toplum düzeninden ileri gelir. Oysa genel hatlarıyla bakıldığında müzakerenin, barışı sürdürmenin başat aracı konumunda olduğu görülür. İnkâr edilemeyen ve büyük deneyimler sonucunda öğrenilen temel olgulardan biri olarak en güçlü ve militarist ülkelerin bile salt güç kullanarak amaçlarına ulaşamadığı yönündeki gerçek, kamu diplomasisinin rolünü gözler önüne serer. 'Her ne pahasına olursa olsun' şeklindeki bir yol haritasındansa diyaloğa dair, ortak çıkarların elde edilmesi ve uzun döneme yayılan bir müzakere daha öncelikli bir konum edinir. Nitekim Machiavelli, devletlerin büyük ordulara sahip olup, tek başına isteğini gerçekleştirebileceği noktada bile diplomasinin gerekli olduğunu söyler (aktaran Berridge, 2001, s. 542). Yine de genel bir tanım çizip sınırlar inşa etmek pahasına tanımlamaya çalışıldığında devletlerarası taraflara dayanan, karşılıklı diyalog ve müzakere yoluyla mevcut ilişkileri korumak veya ilerde sorun oluşturabilecek muhtemel durumlara yönelik her çeşit çabayı, eforu ifade eder, denilebilir. Nitekim Öymen'e göre, diplomasi sadece günlük olaylarla, sorunlarla ilgilenmemekle birlikte "ileride ortaya çıkabilecek gelişmeleri, sorunları tahmin ederek çeşitli olasılıklara göre çözüm önerileri hazırlar" (2003, s. 19). Bu, diplomasinin mevcut 
duruma ve çoğunlukla geleceğe odaklandığını gösterir. Ancak kimi durumlarda çabanın ve müzakerenin, gücü bir payanda gibi kullandığı da olur. Müzakere her zaman çözümü beraberinde getirmediği gibi zorun devreye girmesiyle ya da rızayla ortadan kalkabilir. Müzakere tarafların aba altından sopa göstermesiyle, parmak sallamasıyla son bularak çözüme kavuşturulabilir. Ancak bugün güç kullanmak her ne kadar zaman zaman işlevsel olmuş olsa da savaş tekniklerinin kazandığı korkunç boyut, kitle iletişim araçlarında yaşanan gelişmeler yalnızca gücün tek başına yeterli olmadığını göstermekte, gücün kullanımının sonuçlarının her taraftan görüleceği mecraları bireylere sunmaktadır. Haliyle müzakerenin ön plana çıktığı, sağduyu ve barış diline intiyaç duyulduğu bir çağda, diplomasi cebir ve zorun üstünde bir yerde konumlanır. Fakat yine de, Hobsbawm'ın "aşırılıklar çağı"2 dediği çağ geride kalarak, artık aşırılıkların normalleştiği bir dünya düzeninden, küreselleşmeden söz edilmekte, eş zamanlı olarak da tek bir pazara hükmeden bir kapitalizmin varlığı ve yarattığı sonuçlar göz önünde bulundurulmaktadır. Küreselleşmenin sonuçlarıyla ele alabileceğimiz sermayenin devletlerin tekelinden çıkıp uluslararası şirketlerin de eline geçmesi, gelişmiş kitle iletişim araçları, ekonomik krizlerin her tarafta hissedilebilir olması, çok uluslu şirketlerin mallarının her tarafta görünmesi gibi süreçler kamu diplomasisini ve aktörlerini değişime uğratmıştır. Uluslararası ilişkilerde sadece devletlerin değil, uluslararası sivil toplum kuruluşlarının aktör konumuna gelmesi gibi pek çok aktörün bu faaliyetleri kullanmasını beraberinde getirmiştir. Küreselleşme ile beraber bu aktörler uluslararası ilişkileri ve araçlarını değişime uğratmış ve 2000'li yıllardan sonra diplomasinin yeni bir biçimi olan "kamu diplomasisi" kavramı genişleme alanı bulmuştur. Gilboa, kamu diplomasisinin doğuşunda dünyada medyada gelen değişimlerin başında siyasi hayatta, iletişim teknolojilerinde ve uluslararası ilişkilerde yaşanan değişikliklerin olduğunu belirtir (2006, s. 715).

\section{KAMU DIPLOMASISINE KISA BIR BAKIŞ}

Dünya savaşlarından sonra güç dengelerinin değişmesi, bazı oluşumların ulusların üstünde bir yerde konumlanması (Birleşmiş Milletler, Avrupa Birliği, IMF gibi), teknolojinin gelişmesi, dünyaya dair haberlere her yerden her an ulaşılabilmesi gibi faktörler uluslararası ilişkilerin aktörlerini değiştirmiş, uluslararası ilişkileri ulus devletlerin tekelinden çıkarmıştır. Bunun yanı sıra geleneksel diplomasideki kapalı kapılar

2 Eric Hobsbawm, 20. yüzyllı katliamların, savaşların yüzyılı olarak niteleyerek I. Dünya Savaşı'nın başladığı 1914 yılını ve Sovyetler birliğinin 1991 yılında dağılmasına kadar olan kesintisiz savaş yüzyılını "aşııııklar çağı" olarak adlandırır (Hobsbawm, 2008). Detaylı bir okuma için bkz: (Hobsbawm, 2006) 
aralanmış, kapının her açılışı ve kapanışı anında yankı uyandırabilir, eleştirilebilir hale gelmiştir. Diplomasi, diplomatların bir dönem faaliyet sürdürdükleri mesleğin ötesine geçmiştir. Sıradan vatandaşlar da aktör konumuna gelmiş ve etkili olmaya başlamıştır (Yağmurlu, 2007, s. 11). İlk kamu diplomasisi uygulamalarına Soğuk Savaş döneminde karşılaşmaktayız; Amerikan ve Batı değerlerinin Doğu Avrupa ülkelerine yayılmasına yönelik ikna faaliyetleri içeren bu uygulamalarda yeni gelişen kitle iletişim araçlarının önemli bir etkisi söz konusudur (s. 14). Bu diğer bir açıdan da devletlerin kamuoyunu önemsemelerini zorunluluğa dönüştürmüştür. Daha sonra 1948-1964 yılları arasında kurulan 47 yeni ülke, uluslararası kamuoyunun önemli birer aktörü haline gelmiştir. Berlin Duvarı'nın yıkılısılyla, kutuplu dünyanın sona ermesi kamu diplomasisi uygulamalarını sekteye uğratmış, daha doğru bir ifadeyle kamu diplomasisi faaliyetleri duraklama dönemine girmiştir. Tekrar yüzeye çıkması ise Dünya Ticaret Merkezi'ne yönelik saldırılarla ABD'nin yeniden kamu diplomasisi uygulamalarına başvurmasıyla mümkün olur. Kıta Avrupası'nda ise Sovyetler Birliği'nin dağımasıyla 8 ülkeden 29 yeni ülkenin ortaya çıkması kamu diplomasisini önemli bir araç olarak gündeme getirmiştir (Yağmurlu, 2007, s. 15). Günümüzde bu uygulama biçimlerinin varlığı mevcut olsa da bir dönüşümün yaşandığı ortadadır. Dolayısıyla, bugün, devlet dışındaki aktörleri hesaba katmadan diplomasinin düşünülmesi mümkün görünmemektedir. Küreselleşmenin doğurduğu faktörlerden: toplumların ve politikaların kitle iletişim araçlarından bağımsız tutulamaması, ekonomik gelişmelerden bağımsız görülememesi, uluslararası kamuoyunun rıza ve sempatisinin gerekliliği diğer halkların kamuoyunu etkileme çalışmalarını zorunlu hale getirmiştir.

Kültürel politikalar, ortak eğitim ve destekleme programları aracılığıyla uluslararası kamuoyunun kazanılması noktalarında kamu diplomasisi büyük önem taşımaktadır. İcra edilen kamu diplomasisi uygulamaları teknolojik destekle çok hızı başka uluslara aktarılabilmekte, gelecek nesiller üzerinde yönlendirici etkiler taşıyabilmektedir. Kavramın geleneksel diplomasiden ayrışan yanı kamu diplomasisinin sivil topluma yönelik olması, onu da içermesidir. Bu anlamıyla geleneksel diplomasiden ayrışan kamu diplomasisinde hedef olarak halklar ele alınırken geleneksel diplomaside resmi temsilciler ele alınır (Sancar, 2012, s. 81). "Ağ toplumu" kavramını ön plana atan önemli düşünürlerden Castells'e göre (2008, s. 78) kamu diplomasisi, küresel kamu alanına devletin değil halkın diplomasisi olarak müdahale edip geleneksel diplomasi formları yerine ortak kültürel anlamları iletişimin 
temeliüzerine inşa ederek; güçilişkilerinin, katı müzakerelerin ötesinde uygulama alanı bulmaktadır. Yine Castells'e göre (2008, s. 91), kamu diplomasisi propagandadan ve devlet diplomasisinden ayrışı ve halkın diplomasisi olarak gerçekleştirilir. Kamu diplomasisinin akademik alandaki önemli isimlerinden biri olan Nicholas Cull, kamu diplomasisini "uluslararası bir aktörün yabancı bir halkla ilişkiye geçerek uluslararası ortamı yönetme girişimi" (2009, s. 12) olarak tanımlarken; Manheim "bir devletin çıkarları doğrultusunda uluslararası kamuoyu ya da seçkinlerin düşüncelerini etkileme çabalarının bütünü" (1990, s. 4) olarak tanımlar. Bu açıdan bakıldığında kamuoyunun sürece dahil edildiği açıkça görülür.

Günümüzde hükümetlerin dış politika gayelerini etkili bir şekilde savunabilmeleri, kamuoyunun ve hedef kitlelerinin yanında hedef kitlelerinin iletişimde olduğu çevreyi ne ölçüde etkilediğiyle yakından ilişkilidir (İskit, 2007, s. 413). Politik uygulamalarda, bir kararda haklı olmak tek başına yeterli olmamakta, rızanın üretilmesine, karşılıklı anlayış ve iletişimin doğmasına intiyaç duyulmaktadır. Bu, halkla ilişkiler uygulamalarında da görülen bir durumken, kamu diplomasisini sadece halkla ilişkiler uygulamasından ibaret görmek yanlış bir tutum olarak değerlendirilir (Yıldırım, 2015a, s. 116). Yağmurlu (2007, s. 10), kamu diplomasisi ve halkla ilişkiler arasındaki bağlantıyı ele aldığı çalışmasında kamu diplomasisinin uluslararası ilişkiler ve halkla ilişkilerin kesişme noktasında bulunduğunu söyler. Bir stratejik iletişim aracı olarak kamu diplomasisi karşılıklı anlayış, bilgilendirme ve kamuyu etkilemekten müteşekkildir (Kalın, 2011, s. 11). Halkla ilişkilerle yakın dirsek temasında olmakla birlikte pek çok uygulamasını ve ilişki inşa etme işlevini kullanır. Ancak geleneksel halkla ilişkiler formalarından ziyade Kalın'ın belirttiği gibi (2011, s. 11), stratejik iletişim aracı olarak ele almak daha doğrudur.

Literatürde yüzlerce tanımı yapılan kamu diplomasisini Coombs ve Holladay'ın (2010, s. 299) yumuşak güç3 kullanılarak icra edilen, bir devletin diğer ülkelerin insanlarına doğrudan mesaj iletme, ikna etme, uzun vadede sempati uyandırma aracı olarak ele almak, bir çatı inşa etmek açısından önemlidir. Zira her diplomattan araştırmacıya, halkla ilişkiler akademisyenlerinden siyaset bilimcilere değin geniş bir tanım silsilesi söz konusudur. Fakat uluslararası ilişkilerin bir parçası olarak önemli bir işleve sahip olduğu açıkça görülebilmektedir. Tanımlara baktığımızda birincil amaç

3 Joseph Nye için yumuşak güç, cebre dayanmadan cazibe yoluyla istenilen sonuçlara ulaşma yeteneğidir ve bir ülkenin yumuşak gücü kültürüne, değerlerine, politikalarına yaslanır. Yumuşak güç kullanıllirken herhangi bir ekonomik, militarist tehdite yer verilmez ve dolayısıyla karşılıklı ikna süreci önemli rol oynar. Nye, kamu diplomasisi aracı olarak yumuşak gücün devletler üstü bir yerde konumlandığını ve sivil toplumun da kullandığı bir yöntem olduğunu belirtir (2008, s. 94-95). 


\section{$\operatorname{arts}=$}

olarak bir kamuoyu üretilmesi bunun için de fikir ve değerleri tanıtmak, aktarmak gibi bir hal karşımıza çıkmaktadır. Ama artık sadece hükümetlerden hükümetlere doğru olan bir çizgide stratejik amaçları gerçekleştirmek yeterli olmadığı için de bu amaçlara yabancı halkların dâhil edilmesi, bilgilendirilmesi, amaçlar doğrultusunda yönlendirilmesi, gerektiğinde ikamet ettiği dış politikayı baskılaması gerekir. Bu noktada, iletişim zemininden bakıldığında, rızanın üretilmesi ön plana çıkmaktadır. Elbette kastedilen rıza, Herman ve Chomsky'nin (2012) önerdiği biçimiyle kitle medyasının rızanın üretilmesindeki rolüdür. Rıza üretimine eleştirel yaklaşan yazarlar için rızanın üretilmesi ancak sermaye sahiplerine, çıkar gruplarına hizmet eder (Herman, Chomsky, 2012, s. 15).

Kamu diplomasisinin propaganda modellerini kullandığına ve biçim değiştirdiğine dair yaygın görüşler literatürde yer alırken (Melissen, 2005, s. 3), yabancı halklara bilgi iletmenin ve onları ikna etmek için yönlendirmenin propaganda faaliyetleri içerdiği söylenmektedir. Oysa Joseph Nye (2008, s. 101) propagandanın kamu diplomasisinin amacına ters düştüğünü, kamu diplomasisinin taraflar arası uzun dönemli ilişkiler inşa etmeyi içerdiğini belirtmektedir. Dolayısıyla, amacı propaganda olarak değerlendirmek doğru olmadığı gibi amaç propaganda değil, nesnel gerçeklere ve gerçekliğe dayalı stratejik bir iletişim dili oluşturmaktır (Kalın, 2011 , s. 111 .

Gerçekliğin belirli boyutlarıyla yürütülen süreçte ilişki inşası, diğer ülkelerin insanlarının gündelik pratiklerini, değer olarak gördüğü bütün kültürel formları, bir fikre dair yanlış algıyı ve anlamları değiştirmeye fayda sağlar. Savaş sırasında yapılan diplomasi uygulamaları karşılıklı anlayışı yıkabilir fakat karşılıklı diyalog ve pazarlık zeminine kadar olan süreçte mühim bir zeminde hareket alanı bulur ${ }^{4}$. Ancak bugün kullanılan metoda bakıldığında uluslararası ilişkilerde cebrin ve gücün saklandığı, daha çok rızaya dayalı bir mesaj üretme şekli görülür. Bugün yukarda belirttiğimiz mesajların anında yankı uyandırabilmesi ve yaygınlaşabilir olması iknanın, mesajın zora dayanmasını ıskartaya çıkarır. Bunun yanı sıra küreselleşme sürecinde ikna faaliyetinin hedefin güvenini kazanmaktan başladığı bilinen bir olgudur. Güveni elde etmek için de doğru bilgilendirme, nesnel gerçeklere dayanma ve gerçeklik üzerinden mesaj oluşturma kısımları kamu diplomasisinin kendisinde yer alan ve kamu

$4 \quad$ ABD, Irak'a savaş başlatmadan evvel kendi politikalarını meşrulaştırmak için uluslararası kamuoyunu yanına çekmeye çalışmış, Saddam Hüseyin'in elinde kitle imha silahları olduğunu ve bunun bütün insanlık için sorun teşkil ettiğini duyurmak için elinden geleni yapmışıı. iki zıł kutup ve çıkarların birbirine denk düşmediği, bir tarafın baskın olduğu bir süreçte karşlıklı anlayışın ve ilişki inşasının zaman zaman ve hatta çoğunlukla güçlü olanının işine geldiği bu ve benzeri örneklerde görülebilir. 
diplomasisinden zuhur eden kısımlardır. İnanılır olmak, ikna sürecini gerçekleştirmede önemli bir boyutu teşkil eder.

Sonuç olarak kamu diplomasisi, hedefleri gerçekleştirmek, kendini doğru bir şekilde açıklayabilmek için halkla ilişkiler, propaganda, ulus markalama süreçlerini etkin olarak kullanır. Hepsi olumlu bir imaj elde etmek, imajı yaygınlaştırmak, hedef kitlenin algılarını yönetmek ve uzun süreçte itibar yaratmak için sürece katkı sağlar. Bu noktaların hepsi hedefli iletişim çalışmalarına dayanması açısından da stratejik iletişimle çok yakından ilişkilidir.

Kamu diplomasisi aktörleri bu çalışmaları yürütmek ve diğer ülkelerin halklarıyla iletişime geçmek için mevcut kaynaklarına başvurur. Bunlar arasında uygulama alanları olarak kültürel diplomasi, yurttaş diplomasisi, inanç diplomasisi, lobicilik faaliyetleri ön plana çıkar. Bir ülkenin kültürel faaliyetler üzerinden diplomasi yürütmesi yumuşak gücün icrasını kolaylaştııı ve çekicilik oluşturur. Bir ülkenin kültürü ve ideolojisinin çekiciliği ise diğer ülkeler için zamanla örnek alınabilecek bir faktör olur (Nye, 2008, s. 95).

\section{KAMU DIPLOMASISININ UYGULAMA ALANI OLARAK KÜLTÜREL DIPLOMASI}

Bir ülkenin imajı, itibarı, çekiciliği yabancıların belirli seviyelerde ve biçimlerdeki görüşlerinden meydana gelir. Kamu diplomasisinin uygulama alanları temel olarak kültür, eğitim, medya, teknoloji, spor gibi çerçevelerde değerlendirilir. Küreselleşmenin getirdiği ve hız toplumuyla beraber artık ekonomi ve teknolojideki gelişmelerin yanı sıra kültürel etmenler de çok hızı bir alışveriş sürecinin içerisindedir. Kültürlerarası geçişkenliğin zirvede olduğu bir dönemde, kültürel dinamikler kamu diplomasisinin en önemli aracı konumundadır. Fakat kültürel diplomasiyi kısaca tanımlamak o kadar da kolay değildir. İnsanlar arası ilişkilerde kültür, insanların birbirlerini nasıl algıladıklarının ve farklılıklarını nasıl müzakere ettiğinin majör belirleyicisi konumundadır (Holden vd., 2007, s. 18). Bu açıdan bakıldığında kültürel diplomasi bir taraftan kültürler arası alış verişi vurgularken, diğer taraftan uluslara içkin olan değerleri uluslararası kamuoyuna bir norm olarak sunmayı kapsar (Yağmurlu, 2019, s. 1184). Kültür ülkeler arası uygulamalarla politize edilerek kamu diplomasisi aracı olarak kullanıır. İçinde yer aldığı insan topluluklarının özelliklerini ve alışkanlıkıarını birbirlerinden ayıran kültür, insan etkinlikleri sonucunda meydana gelen her şeyi kapsar. İnsanın ortaya koyduğu, insan eliyle var olan tüm gerçeklikler bu tanımın 


\section{arts}

içerisine girer (Uygur, 2003, s. 17).

İnsandan insana aktarılan ve insan elinin değdiği herşey günümüzde çokraha† bir şekilde nesilden nesile aktarımanın yanı sıra teknolojideki gelişmeler vasıtasıyla farklı toplumlara aktarılabilir ve çok rahatlıkla dönüşüp değişebilir vaziyettedir. Bugün olumlu olarak değer görülen her olgu, kısa bir süre sonra olumsuz ve değersiz görülebilir haldedir. Buna paralel olarak kültür formlarını oluşturan sinema, edebiyat, müzik gibi sanatsal etkinlikler ve bu sanatların icrası vuku bulduğu topraklarda değil, farklı kültürel zeminlerde rahatlıkla yayılır. Yayılma sonucunda hedefli kültür politikaları olumlu bir anlam bularak ikna sürecini kolaylaştııı ve kültürel diplomasi olgusunu karşımıza çıkarır.

Kültürel diplomasi tıpkı yukarda değindiğimiz kamu diplomasisi gibi ama onun alt bir uygulama alanı olarak toplumların dış ilişkilerinde, barış zamanlarında önemli bir işlev görür. Samimi ilişkilere dayandığından daha gerçekçi olarak görülür (Mitchell, 2015). Kültür insana dair olduğu, tüm insan etkinliklerini kapsadığı için de yabancı toplumdaki insanlara yine bu insani yön ve değerlerle iletişime geçildiğinde, duygu ve düşünce dünyasındaki olumlu değişimleri hızlandıır. Zira küresel dünyada benzerliklerin arttığı bir dönemde dahi kültürel öğeler farkllıkları devam ettirmekte ve toplumlar bu durumu kendi üstün özellikleri biçiminde uluslararası kamuoyuna sunma intiyacıyla hareket etmektedir (Yağmurlu, 2019, s. 1184).

Kültür ve diplomasi kavramlarından müteşekkil kültürel diplomasi kavramı hakkında pek çok tanım bulunur. Belanger, kavramı kültür ve benzeri birtakım ortaklıkları içeren dış politika faaliyetleri olarak tanımlarken (1999, s. 678), L'Ełang 5 ise duygusal bağlar kurmayı hedefleyen, uzun dönemli kampanyalar gerçekleştirmek olarak tanımlar (2009, s. 610). Barış zamanlarında yumuşak güç olarak kullanılan kültürel diplomasi, barışı sürdürmenin, barış içinde yaşamanın anahtarı olarak değerlendirilebilir. Dolayısıyla aktörlerin konumu burada önem kazanır. Kaynaklara bakıldığında dış politika amaçlarına yönelik hedefli bir mesaj iletme kaygısı taşıması açısından Clarke, kültürle etkileşimde olan kurum ve kuruluşları, resmi temsilcileri ve kişileri aktörler olarak ele alır (2016, s. 154). Aynı zamanda bu aktörlerin mesajları nasıl aldığı, nasıl paylaştığı, kültürel anlamları nasıl tartıştığı da aktörleri belirlemek için önem taşır (Clarke, 2016, s. 156). Dış politika hedefleri barış zamanında ikna ve olumlu imaj yaratmak, yaratılan imajı pekiştirmek için yapıldığından devletlerarası

$5 \quad$ L'Ełang, kamu diplomasisi ve halkla ilişkilerin kesişen izleklerini belirterek diplomasi faaliyetlerinin halkla ilişkiler disiplininin araçları kullanıldığında daha etkili olacağını savunur. Kamu diplomasisi ve halkla ilişkilerin entegrasyonu ile gerçekleştirilen faaliyetlerin etkili sonuçlar doğurabileceğini belirtir (2009, s. 620). 
olarak gerçekleşen kültürel diplomasi çok da inandırıcı olmayabilir; dolayısıyla daha çok sivil toplum eliyle faaliyetler gerçekleştirilir. Devlet, kültürel diplomasi noktasında daha çok destekleyici ve yönlendirici bir işlev görür (Purtaş, 2013, s. 5). Üstelik uygulamalara bakıldığında kültürel diplomasi faaliyetlerinin sadece resmi temsilciler eliyle değil, sivil toplumdan düşünürlere, akademisyenlerden sanatçılara değin geniş bir katııımın olması sağlandığında başarıya ulaştığı görülür (Fatima \& Khan, 2018, s. 10). Kamu diplomasisini bilgilendirme ve kültürel çabalar olarak ayıran Signitzer ve Wamser (2006, s. 438), bilgilendirmenin dış işleri eliyle gerçekleştiğini söylerken kültürel çabaların ise özerk ve yarı özerk kurumlar eliyle yürütüldüğünü dile getirirler.

Uygulamalardaki başarılı örneklere bakıldığında da kamu ve sivil toplumun ortaklaşa yürüttüğü faaliyetler görülür. Yalnızca devletler ve hükümetler eliyle yürütülen kültürel diplomasi faaliyetleri de varlık alanı bulurken, bireysel bazda da kültürel diplomasi faaliyetleri gerçekleştirilmektedir. Söz gelimi bir ülkenin yazarının Nobel Edebiyat Ödülü'ne değer görülmesi, o ülkenin edebiyatını ve dolayısıyla insan olma hallerini ve kültürünü merak konusu kılar. Buna benzer pek çok faaliyeti içeren kültürel diplomasi, edebiyat festivallerinden müzik festivallerine, konserlerden tanıtım kampanyalarına, resim sergilerinden edebiyat çevirilerine, kütüphanelerden dinler arası diyaloga kadar geniş bir alanda hareket alanı bulur. Bu yüzden aktörler bugün, küreselleşme sürecinde tüm insan grupları olarak ele alınabilir. Akademik anlamda yapılan çalışmalara bakıldığında da uygulama alanlarının ve araçlarının bu çeşitliliği rahatlıkla görülebilir.

Kültürel diplomasinin bir köprü işlevi gördüğü kuşkusuz bir gerçektir. Ama bazen köprüler tek yönlü olabilir ve köprüler birinden diğerine sadece tek yönlü bir geçiş sağlayabilir. Kültürel diplomasi ise çoğunlukla gidiş ve gelişlerin olduğu iki yönlü bir köprü olarak tasvir edilebilir. Örnek vermek gerekirse, iki yönlü bir köprü işlevi gören kültürel diplomasi, müzik, edebiyat, resim konularında Soğuk Savaş sırasında ABD'de doruk noktasına ulaşmıs; ABD'li müzisyenler (Louis Armstrong, Dizzy Gillespie, Charlie Parker) Mısır, Nijerya gibi pek çok ülkede turneler düzenleyerek, seçkinlere hitap etmektense sıradan insanlara konserler vererek onların sempatisini kazanmaya başlamışlardır (Schneider, 2006, s. 192). Soğuk Savaş döneminde özellikle açılan Amerikan Kültür Merkezleri, kültürel diplomaside önemli rol oynamıştır (Schneider, 2006, s. 193). Bu uygulamalar kısa vadeli olarak ele alındığında başarıya ulaşması ve uzun dönemli hedefleri gerçekleştirmeye yardımcı olması; imaj, itibar ve ikna için çok da mümkün değildir. Oysa kültürel diplomasinin temel özelliklerinden biri 


\section{arts}

de başta belirttiğimiz gibi uzun dönemli faaliyetleri içermesidir. Yani bir süreklilik arz etmesi, uzun dönemli sonuçların alınması beklenir (Ünal, 2019, s. 615).

Süreklilik arz eden uygulamaların başında da dil ve eğitim gelir. Devletlerin kendi dillerini yaygınlaştırması o devletin kültürünün ve sanatının öğrenilmesine, kültür ve sanat aracılığıyla bireylerin birbirleriyle iletişime geçmesine olanak sağlarb (Sancar, 2012, s. 170). 1907 yllında kurulan Fransız Kültür Merkezi bu anlamda başarılı bir girişim şeklinde değerlendirilir. Elbette bütün bu kültürel faaliyetlerin nihai hedefleri arasında siyasi etkileşimin önünü açmak, kolaylaştırmak ve uzun dönemli amaçları gerçekleştirmek vardır. Günümüzde üniversiteler arasında gerçekleşen öğrenci değişim programları, ziyaretler, burslar bu alandaki çalışmalara örnek gösterilebilir. 1930 yllında kurulan Alman Akademik Değişim Sistemi (DAAD) projesi, yüksek lisans eğitiminden yazar burslarına kadar geniş bir spektrumda 60 ülkede kurduğu ağla dünyanın her köşesinden öğrencilere ve araştırmacılara burs olanakları sunan, ülkeler arası akademik iş birliklerini destekleyen başarılı bir sistem olarak ele alınır . Buna örnek olarak neredeyse her ülkenin girişimleri mevcut olsa da en başarılı örnekler arasında ABD'nin Fulbright Programı, İngiltere'nin British Council, Almanya'nın Goethe Enstitüsü faaliyetleri gösterilmektedir. Kurumlar kendi ülkelerinin imaj çalışmasını ve diplomasi faaliyetlerini bu kurumlar aracılığıyla yürüterek imajlarını genişletmeyi amaçlar. Tarihsel olarak, örneklerden de görüleceği üzere kültürün anlatılması, yaygınlaştıııması bir dış politika hedefi olarak karşımıza çıkmıştır. Yağmurlu'ya göre kültürel diplomasinin başlangıcı dil eğitimi ve kültür enstitüleri olarak ifade edilebilir (2019, s. 1185).

Kültür ve diplomasiden zuhur eden kültürel diplomasi, uluslar ve halklar arasında sanat, bilgi, fikir alışverişlerini hızlandırmak amacıyla gerçekleştirilen tüm çabaları ifade eder. İşbirliği ve siyasi süreçlere katkı sağlayan kültürel diplomasi devlet destekli olabildiği gibi, bireysel yollarla da genişleme alanı bulur. Kültürel diplomasi, kültürün güçlü yönleri ön plana çıkarılarak yapıldığında başarıya ulaşır, insana dair tüm yönleri ve faaliyetleri kapsar. Bu faaliyetlerin tümü iki yönlü diyalojik model ve köprü inşasında önemli bir rol oynar. Küreselleşen dünyada artık uzun dönemli kültür politikaları öncelenmekte ve diplomasi faaliyetlerinde direkł devlet

\footnotetext{
$6 \quad$ Ingiltere menşeili BBC televizyonu, dil öğreten uygulamalarla kendi dilini yaygınlaştırmaktadır. Bu açıdan doğal olarak dille ilişkisi olan her birey öğrendiği dilin kültürüyle de temasa geçmektedir. Bu anlamda Türkiye'deki devlet televizyon kanalı olan TRT World böyle uygulamalara kapı aralayarak Türkiye kültürünü yaygınlaştırabilir ciddi bir potansiyele sahiptir.

7 DAAD kuruluşundan bu yana 2 milyona yakın kişiye olanak sağlamasıyla sadece burs veren bir kuruluş değil aynı zamanda Almancanın yaygınlaşması, Alman kültürünün öğrenilmesi amacıyla faaliyet gösteren bir kuruluştur.

https://www.daad-turkiye.org/tr/hakkimizda/daad-hakkinda/ (Erişim tarihi: 04.11.19).
} 
eli olmadığı için kültür politikalarının ikna ve karşılıklı anlayışta daha samimi bir rol oynadığı düşünülmektedir (Purtaş, 2013, s. 4).

Kültürel diplomasi alanındaki faaliyetleri önemseyen devletler, çeşitli enstitüler kurarak varlık alanlarını genişletmeye çalışır (Ünalmış, 2019, s. 138). Türkiye'nin dış politikasında son yıllarda buna dair atılan başlıca adımları Yunus Emre Enstitüsü ve Yurtdışı Türkler ve Akraba Topluluklar Başkanlığı (YTB) birimleri oluşturur. Türkiye, bu anlamda ciddi bir potansiyele, hinterlanda sahiptir ${ }^{8}$. Kültürel diplomasi faaliyetleriyle güçlü bir imaj yaratabilir, kendini doğru şekilde ifade edebilir, ulus-markalaşma sürecini güçlendirebilir (Özkan, 2015, s. 8). Ülkeler kamu diplomasisini ve araçlarını kullandığında dikkat merkezi olacağı için uzun dönemde kendi politik süreçlerinde destekçi, pasif bir kitledense aktif ve refleksler alabileceği aktif bir kitle edinir. Kültürün bileşenlerinden biri olan edebiyat bu anlamda, önemli bir işleve sahiptir.

\section{KÜLTÜREL DIPLOMASI BAĞLAMINDA EDEBIYAT DIPLOMASISi}

Edebiyatın dışpolitika hedefiolaraknasıl kullanıldığına bakmak, Türkiye örneğini daha da somutlaştırmak adına diğer ülkelerdeki kullanım şekillerine odaklanmak önem teşkil eder. Dolayısıyla bu başlık altında, ABD, Çin, Fransa, Almanya, Rusya ve İngiltere' deki kültürel diplomasi faaliyetlerinde edebiyatın alanına odaklanılacaktır. Fakat çalışmanın Türkiye ile sınırlandırılması; makalenin edebiyat ve kültürel diplomasi arasındaki ilişkiyi kavramsal olarak ele alması hususları göz önüne alındığında, kısa değinilerin yerinde olacağı düşünülmektedir.

Kültürel diplomasi aracı olarak edebiyat literatürde çok sık tartışılan bir konu olmasa da bu alana dair giderek çalışmaların artığı görülmektedir (HaddadianMoghaddam, 2016; Yağmurlu, 2019; Bo, 2018). Tarihsel olarak bakıldığında bu anlamda en geniş yatıımı yapan ülke ABD'dir. ABD, kendi karşıtı düşünceleri etkisiz hale getirmek, farklı bir imaj oluşturmak için uzunca bir süre Amerikan kültürünü yaygınlaştırmanın yollarını aramıştır. New York merkezli Franklin Kitap Programları ${ }^{9}$

\footnotetext{
$8 \quad$ University of Southern California Center on Public Diplomacy ve Portland'ın ortaklaşa yürüttüğü ve on binlerce katılımcı ile gerçekleştirilen anket çalışmasına göre Türkiye 2017' de yumuşak güç sıralamasında son sırada yer alırken, Fransa 1.sırada yer almış, Türkiye 2018' de sıralamaya girememiş ve 2019 yllı verilerine göre ise 29. sırada yer almışıı (McClory, 2017; 2018; 2019). Altı kategoride objektif verilerle ölçülen araştırma kategorilerini kültür, eğitim, katıım, dijital, kurum ve hükümet başıkları oluşturmakta. Araştırma verilerine baktığımızda Türkiye'nin yumuşak gücünü meydana getiren faaliyetler içerisinde kültür son sırada yer alırken; ABD eğitim, kültür ve dijital dünyaya bağlanma açılarından birinci sırada yer almaktadır. Türkiye dijital dünyaya bağlanma sıralamasında 12. sırada yer alır. Yine işletme, eğitim, hükümet kategorilerinde son sıralarda yer alırken uluslararası alanda sahip olduğu elçilik, kuruluş üyelikleri açısından 9. sırada yer almaktadır. Rapor kültürel diplomasiye verilmesi gereken önemi gözler önüne sermektedir.

9 Franklin Kitap Programları (Franklin Book Programs), 1952 yllında kurulmuş ve Amerika edebiyatından ve dilinden kitapların, gelişmekte olan ülkelerin dillerine çevirmek ve yayımlamak amacı taşıyan bir programdır (Filstrup, 1976).
} 


\section{arts}

aracılığıyla Mısır, İran, Pakistan, Irak, Lübnan gibi pek çok Ortadoğu ve Asya ülkelerinde merkezler açıp fonlar sağlamıştır. Mümkün olduğunca imzasını geri planda tutup çalışanların hepsini yerel halktan seçmiş, Amerika Edebiyatı'ndan çevrilecek eserlere yine orada yaşayan halkın karar vermesini istemiştir (Haddadian-Moghaddam, 2016, s. 375). Böylece, Amerikan kültürünü tanıtabilecek ve direkt hedef odaklı görünmeyerek, gücün arkasındaki kişi ve kurumları geri planda tutacak, bağımsız bir kuruluş gibi hareket etmeye çalışacaktır. Robbins, aşııı uçta bir tabir kullanarak bu durum için "ABD, uzunca bir süre Ortadoğu'yu kitaplarla bombalamaya çalışmıştır" demektedir (Robbins, 2007, s. 648). Kitapların yanı sıra müzik ve sinemaya da çoğu kez başvurmuş (Fatima ve Khan, 2018, s. 12), zaman zaman bazı yazarları kültürel elçiler olarak kullanmıştır (Nawotka, 2013).

Son dönemde Çin hükümeti, edebiyat aracılığıyla yürürlüğe koymaya çalıştığı kültürel diplomasi faaliyetleri için ülkelere yapılan bazı resmi gezilerde roman yazarlarını da heyetle götürmeye başlamıştır. Ekonomik alışverişin çok yüksek olduğu Çin, kültürel alışveriş noktasında yetersiz kaldığı için de bu alana öncelik vermiş ve 2013 yılında Çin Kamu Diplomasisi Birliğini kurmuştur. Latin Amerika'ya yapılan bir gezide Çin yetkililer, edebiyatın ihracałı başkalarının yerli kültürünü ve düşünce tarzını etkileyecek ruh ve düşünme biçimlerinin ihracıdır, demektedir (South China Morning Post, 2019).

Almanya, kültürel diplomasi aracı olarak edebiyatı tekil bir alanla değil, programlı bir kamu diplomasisi faaliyetleriyle gerçekleştirir. Berlin Senatosu Misafir Sanatçı Programı, Almanya ve Türkiye arasındaki kültürel etkileşimi sağlamayı amaçlar. Programın hedefi, sanatçıların ev sahibi ülkenin kültürünü, yerel sanat ortamını tanımayı, bu kapsamda fikir alış verişlerinde bulunmayı sağlamaktırio. Yine son yıllarda Goethe Enstitüsü (1951) işbirliğiyle gerçekleştirilen LiteraTür projesi, Türkçe ve Almanca edebiyat arasında yeni bir kapı açmayı hedeflemektedir. İki dil arasında yeni köprüler inşa etmeyi amaç edinen proje, iki dilde edebiyatı bir kavram ekseninde tartışmaya açar. Her temada biri Türkiye' den biri de Almanya'dan olmak üzere iki küratörle kavramlar iki ülkenin yazarları tarafından tartışlır. Bu sayede iki ülke edebiyatının benzerlikleri, farklılıkları ve özel alanları gözler önüne serilir. Proje kapsamındaki yazı ve söyleşiler iki dille hazırlanmakta, video ve yazılı röportajlarla

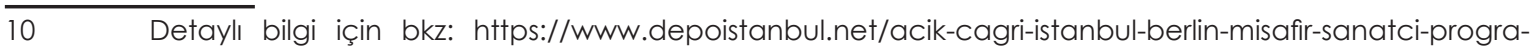
mi-2021-2022/ 
okurlara sunulmaktadır ${ }^{11}$.

2021 yılında Fransız Kültür Merkezi eliyle yürürlüğe girecek Fransızca Çeviri Ödülleriyayımlanmış eserlerin Fransızcadan Türkçeye çevirisini desteklemekte ve teşvik etmektedir. Fransız dilini tanıtmakta önemli bir rol oynamayı amaç edinen projede, çevirmenlik mesleğinin de güçlendirilmesi hedeflenir ${ }^{12}$. Çevirinin bir kültürel diplomasi aracı veya kültürel etkileşim aracı olarak kullanılması kuşkusuz en eski projelerden biri olmakla birlikte, en etkili yöntemlerden biri olduğu söylenebilir. Örneğin Rusya'nın dış ülkelerle karşııklı etkileşimi yaratması noktasında diğer medeniyetleri en çok etkileyen kültür unsuru olarak edebiyat ön plana çıkar. Özellikle 17-19. yüzyıl arasında Rusya'nın dış ülkelerdeki kültürel temsilcisi edebiyat eserleri olmuştur. Bunlar Rusya toplumuna, kültürel yaşamına, sosyal ilişkilerine dair bir harita işlevi görmüşłür. Fakat Sovyetler Birliği'nin yıkılmasıyla süreç sekteye uğratılmış ve kültürel diplomasi faaliyetleri zayıf kalmıştır. 2008 yılından bu yana Rusya Dışişleri Bakanlığı tarafından atılan adımlar, Rusya'nın kültürel işbirliğine katıımını önceleyen faaliyetleri kapsamaktadır (Sak ve Adilbekova, 2015). Yukarıdaki örneklerden de görüleceği üzere, kültürel diplomasi faaliyetleri içerisinde yer alan edebiyat metinlerinin somut adımlarla desteklenip dış politika hedeflerinde bir aracı rol üstlenmesi, kültürel diplomasi faaliyetleri açısından önemli bir işlevi yerine getirir. Kalıcı ve uzun dönemli olması ise Nye'ın belirttiği yumuşak güç unsuru olarak kullanılabilirliğini kanıtlar niteliktedir.

İngiltere'de edebiyat ve diplomasi ekseninde kesişen en belirgin örnek olarak Harry Potter serisi sayılabilir. Serinin çok güçlü bir şekilde uluslararası yaygınlığı, gerek ticari açıdan gerekse de turistik ve kültürel açıdan İngiltere'ye çok büyük getiriler sağlamıştır. Önce kitap olarak basılması ardından, filmlere dönüşmesi ve serinin yüze yakın dile çevrilmesi başarılı bir kültürel diplomasi örneğini oluşturur. Harry Potter serisi bu anlamda "Harry Potter endüstrisi" olarak da okunabilir. Zira 2017 yllı sonuyla İngiltere ekonomisine 25 milyar dolarlık bir katkı sağlamıştır (Financial Times, 2017). Yukarıda verilen örnekler sadece kültürel diplomasi faaliyetlerinin bir parçasını meydana getirir. Bu faaliyetlerin doğal, akışında yürüyor olması sert ve yumuşak gücü ayırt etmemize olanak sağlar. Bir edebi eseri ya da kültür formunu çekici hale getirmeden, kalıcı ve uzun vadeli fayda sağlaması mümkün değildir. Bu anlamda bu çekiciliği sağlayacak olanlar da ülkelerin kültür bakanlığı ve kurumsal pratikleridir. Dolayısıyla bu noktadan itibaren öncelikle edebiyatın kültürel diplomasi ile olan ilişkisine ve bunun Türkiye' deki uygulama pratiklerine bakılabilir.

11 Detaylı bilgi için bkz: https://www.goethe.de/ins/tr/tr/kul/sup/lit.html

12 Detaylı bilgi için bkz: https://www.ifturquie.org/fransizca-ceviri-odulu/ 


\section{arts}

Kitaplar -özelde edebiyat- okuru başka bir kültürle tanıştırma noktasında önemli bir işleve sahiptir. Okurun kitabı eline aldığında orada kendini bulabilmesi eşsiz bir deneyim olmanın yanı sıra farklı yerde, farklı kültürde, dünyanın bambaşka bir kasabasında ya da kentinde kendi gibi birinin olduğunu görmesine, onun yaşamsal çevresiyle ilişkiye girmesine olanak sağlar. Ełkisine kapıldığı metin ve okuru arasında birdenbire mesafe ortadan kalkar, bir yakınlık meydana gelir. Böyle bir durumda okur, metne, olaya ya da kurguya çağrımış olur; daha önce görmemiş bir şeyi görmenin gururu ve tatmini açığa çıkar. Okur, metin aracılığıyla gözlerini kendinden başka olana çevirerek, kendine, kendi olan neyse ona farklı bir gözle bakmaya başlar (Felski, 2013, s. 38). Edebiyat, okuru metinler yoluyla kendine ve kendiliğe dair ne varsa onu uyandırmaya davet eder. Kişiyi kendi aynasına yakınlaştıır. Kendisini bir öteki, bir olay, bir durum, bir diyalog üzerinden tanımasına yol açar. Bir şeyi tanımak, onun ayırdına varmayı ve böylece onu yeniden bilebilmeyi, mevcut durumda var olan, gerek bilinen gerekse bilinmeyen bir şeyle ilişkilendirmeyi imler (Felski, 2013, s. 39). Bu, aşina olunandan fazlasını bilmeye tekabül ederek benliği kendi üstüne düşünmeye daveteder. Özellikle roman, bilincin ve anlamlandırılamayan kıvılcımların üstüne düşünmeye, kişinin kendisi ve toplum arasındaki bağları aydınlatmaya kucak açarak, psikolojik farkındalık sağlar. "Kişi aynı şeyi yapan başkalarını örnek alarak kendisi olmayı öğrenir" (Felski, 2013, s. 40).

Edebiyat, yaşanılan durumu, gerçekliği, artık ışığı sönmek üzere olan bir geçmişi hatırlamaya, bakış bahçesine çıkararak görmeye, algılamaya yardımcı olarak, bireylerin yaşadığı pişmanlıklar karşısında telafi edilemeyecek şeylerin olduğunu hatırlatır (Şüküran, 2019, s. 15).

Fakat edebiyata yüklenen bu aşırı misyonu edebiyat çoğu zaman sırtlayamaz. Var olan tüm sorunlara cevap vermeyeceği için de her şeyi masaya yatırmasını beklemek doğru olmadığı gibi, diğer yandan, yukarıda kısaca değindiğimiz durumlar üzerinden bir birliktelik, paylaşım yaratabilir, kişiyi kendi aynasına yakınlaştırabilir. Durum neyse onu açığa vurabilir. Ancak bir edebi metni okumanın tek kişilik bir pratik olduğu bilinen bir gerçektir. Ne var ki, metinler dünya üzerinde doğrudan etkide bulunma kudretine sahip değildir ve yalnızca onları okuyanlar aracılığıyla dünyaya dair bir söz söyleyebilir, etkide bulunabilir (Felski, 2013, s. 29). Edebiyatın etkisi uzun vadeli olmakla birlikte, siyasi ve toplumsal olarak fikirlerin taşıyıcısı olmayı uzunca bir süre omuzlayabilir fakat daha çok politik mücadelelerde bir payanda işlevi gördüğü 
söylenebilir (Yıldırım, 2020, s. 71).

Öyleyse, kültürü ve bizatihi yaşama dair her şeyi bulabileceğimiz edebiyat diplomasi aracılığıyla neden düşünülmesin sorusu burada anlam kazanır. Edebiyat metinleri her zaman doğrudan siyasal mesaj kaygısı gütmüyor olsa da yazıldığı dilin kültürü hakkında bilgi vereceği için o kültürü merak konusu kılar. Böylece diğer uluslarla yapılacak kamu diplomasisi faaliyetlerinde bilgilendirme ve anlama konusu önceden edebiyat metinleri aracılığıyla gelişeceği için politikaların uygulanmasında yardımcı bir işlev görür. Bu yönüyle edebiyat diplomasisi, bir ulusun kültürü ve insan olma hallerini kurgusal, yarı kurgusal veya diğer edebi biçimler aracılığıyla başka uluslara aktarmak, edebi metnin üretildiği mekânları ve kültürü tanıtmak, böylece doğrudan ilişki inşasını gerçekleştirmese de uygulanacak politikalara yardımcı olmak şeklinde değerlendirilebilir.

Edebi metinler ayrıca ülkelerin sürekli muhatap olduğu konularda da okuyucuya mesaj ileterek ya da bir durum tespiti yaparak gücünü gösterir. Örneğin Türkiye'nin iç ve dış politikada muhatap olduğu azınlık meselelerini bireysel bir hikâyeden başlatarak toplumsal bir alana kaydırır. Çünkü bir ülkenin sınırları dışında yaşayan biri ötekinden gelen deneyimler ve buna bağlı olarak verilen enformasyonla bir kanaat geliştirir. Son dönemde Fransa menşeili yayıncı Kontr Editions Türkçe'den Fransızcaya çeviri kitapları yayımlamaktadır. Çevrilen metinlere baktığımızda özellikle Kürt kökenli yazarların metinlerini Fransa vatandaşlarına ulaştırmakta, böylece buradan Türkiye'nin sürekli muhatap olduğu Kürt sorununu edebiyat aracılığıyla oradaki halklara iletmektedir. Kitapların okunmasının uzun süreceği düşünülerek edebiyat, mesaj verme açısından dezavantajlı görünse de (Sancar, 2012, s. 196), kitaplarla verilen mesaj doğru şekilde alıcıya ulaştığında kalıcılığı ve yaratacağı etki çok daha uzun dönemli olabilmektedir ${ }^{13}$.

Bu anlamda Kültür ve Turizm Bakanlığı'nın Türk kültür, sanat ve edebiyatının yurtdışında tanıtılmasında bireksiklikolarakgördüğü noktayı, Türkçe eserleriuluslararası okurlara ulaştırmak amacıyla doldurmaya çalışıı̆ı̆; 2005 yılında başlatılan ve kısa adı TEDA olan "Kültür ve Turizm Bakanlığı Türk Kültür, Sanat ve Edebiyat Eserlerinin Dışa Açılımını Destekleme Projesi" son dönemde nicelik olarak çok sayıda kitabın yabancı dillere çevrilmesine aracılık etmiştir. Proje, Türkçe edebiyat ve kültür, sanat alanında yayımlanmış eserlerin çeviri ve yayım aracılığıyla yurtdışında tanıłımasını sağlamak üzere yurt dışında faaliyet gösteren yayıncılara teşvik veren bir tanıtım ve

$\overline{13}$ Bu anlamda Boris Pasternak'ın Doktor Jivago kitabının hikâyesi ilginç bir örnektir. Bkz: (Pasternak, 2014). 


\section{$\operatorname{arts}=$}

destek programından müteşekkildir ${ }^{14}$.

Türkiye'de çeviri edebiyatın siyasi ve kültürel bir program, bir modernleşme projesi kapsamında kullanılması 1940'lı yıllarda dönemin Milli Eğitim Bakanı Hasan Ali Yücel bakanlığında kurulan Tercüme Bürosu aracılığıyla gerçekleşir. Bu kapsamda Batı ve Doğu'nun kanon eserleri Türkçeye kazandırılır (Bora, 2021). Dolayısıyla TEDA projesi, kurumsal anlamda ikinci bir çeviri seferberliği olarak adlandırılabilir. Birinci çeviri seferberliği, hümanisł kültür mirasıyla ilgili metinlerin Türkçeleştirilmesini kapsarken, bu kez Türkçe edebiyatın önemli eserleri dünya dillerine aktarılmaktadır. Dıştan içe doğru gelişen şey, 2005 yılından beri kurumsal anlamda, içten dışa doğru bir seyir izlemektedir. TEDA projesi kapsamında 2005-2019 yılları arasında Türkçe edebiyattan 2555 kitap 60 farklı dilde çevrilmiştir. Bu noktadan bakıldığında, yabancı halkların hedef kitle seçilmesi önemli bir kültürel diplomasi faaliyeti olarak karşımıza çıkmaktadır. TEDA projesini kolaylaştıran ve yaygınlığını sağlayan noktalar olarak Orhan Pamuk'un 2006 yllında Nobel Edebiyat Ödülü'ne layık görülmesi ve 2008 Frankfurt Kitap Fuarı'nda konuk ülke olarak Türkiye'nin katılması sayılabilir. Proje, başta roman ve şiir alanında olmak üzere tarih, tiyatro, gezi ve inceleme türlerinde eserlerle desteklenmektedir. Türkçe edebiyatta en çok talep gören yazarlar arasında sırasıyla ilk üçte Orhan Pamuk, Orhan Kemal ve Ahmet Hamdi Tanpınar isimleri bulunur (Sağlam, 2014, s. 91). Yıldıım (2015b), TEDA projesinin daha geliştirilebilir olduğuna dikkat çekerek, bu alanda atılan adımların ve yapılan yatıımların artmasıyla projenin etki alanının genişleyeceğini düşünür.

Çeviri faaliyetleriyle başka uluslara aktarılan metinler, metnin yazıldığı dilin kültürünü, insan olma hallerini, yazıldığı dönemde esen politik rüzgârları, devletlerin bireylere karşı tutumlarını, bireylerin devlete karşı tutumlarını geniş bir yelpazede diğer uluslara aktarıı ${ }^{15}$. Aynı zamanda metinlerin yazarları yaptığı söyleşiler, katılığı konferanslar aracılığıyla da metinleri ve metinlerin yazıldığı koşulları dile getirir. Söz gelimi Orhan Pamuk'un 2006 Nobel Edebiyat Ödülü alması, aynı yıl Times dergisinde dünyanın en etkili 100 kişisinden biri seçilmesi sonrasında yaptığı ve yapacağı tüm konuşmalar Türkiye'yi bağlar durumdadır. Bu anlamda edebiyatçıları, kamu diplomasisi bağlamında kanaat önderleri olarak ele almak mümkündür. Kanaat önderlerinden gelen mesajların daha anlaşılır ve güvenilir olduğu, etkilemeye 14 Detaylı bilgi için bkz: (https://teda.ktb.gov.tr/).

15 Bu politik atmosferin yer bulduğu metinlere baktığımızda liste hayli kabarıktır ki Türkiye için 12 Eylül, 12 Mart gibi önemli dönemleri, Türkiye tarihini karşıt bir yerden tarihselleştiren, alternatif bir tarih yazıcılığı geliştiren, anlatan metinler incelenebilir. Bkz: Melih Cevdet Anday'ın Gizli Emir ve İsa'nın Güncesi; Adalet Ağaoğlu'nun Bir Düğün Gecesi ve Ruh Üşümesi; Çetin Altan'ın Büyük Gözaltı gibi kitapları başlıca örnekler arasında değerlendirilebilmektedir. 
daha müsait olduğu açıktır. Bunlar yumuşak güç avantajları olarak kullanılabilir ve dolayısıyla Nobel, Man Booker, Plutzer gibi ödüller önemli yumuşak güç örnekleri şeklinde ele alınabilir. Örneğin Pamuk'un açıklamaları Türkiye algısıyla yakından ilişkilidir, yine 2019 Man Booker ödülünde adı geçen Elif Şafak'ın açıklamaları uluslararası kamuoyunda Türkiye ile ilişkilendirilir. Bu noktada eserleri farklı dillere çevrilerek, diğer ülke halklarıyla buluşturulan Zülfü Livaneli, Sabahattin Ali, Ahme† Hamdi Tanpınar, Pınar Kür, Hakan Günday, Hasan Ali Toptaş gibi yazarların eserleri de edebiyat diplomasi altında değerlendirilebilir. Bu yazarlar arasında yukarıda da görüldüğü üzere, özellikle Tanpınar, Kültür ve Turizm Bakanlığı'nın TEDA projesi sayesinde eserleri diğer dillere en çok tercüme edilen Türkiyeli yazarların başında gelmektedir. Yine Halide Edip Adıvar'ın İngilizce dilinde yazılıp yayınlanmış eserlerinin sonradan ulusal olarak tefrika edilmesi edebiyat ve diplomasi ilişkisinin önemli bir sonucu olarak görülebilir. Zira kamu diplomasisinde ilişki inşası ve çift yönlü diyalojik model ancak kültür merkezli yaklaşımlarla gerçekleşebilme potansiyeline sahiptir. Çünkü diyalog bireyler arasında, eşitler arasında başlar ve toplumsal bir zemine kayar. Bireyler arasındaki diyalog, uygarlıklar arasında da gelişecek diyaloğa olanak sağlar (Cowan ve Arsenault, 2008, s. 16). Cowan ve Arsenault'a (2008, s. 21) göre kültür ürünleriyle yaratılan bu diyalog, ilişki inşasındaki en temel araç olduğu gibi kamu diplomasisini propaganda, lobicilik gibi faaliyetlerden ayırır. Gerçekten de bugün baktığımızda kültür merkezli politikaların ilişki inşasında önemli bir rol oynadığı (dilden eğitime, edebiyattan müziğe, sinemadan festivallere) açıkça görülebilirt .

Fuarlara gönderilen yazarlar kamu diplomasisi için oldukça önemli bir işleve sahiptir. Örneğin 60. Frankfurt Kitap Fuarı'nın açılış konuşmasında Orhan Pamuk, Türkiye' deki demokrasi anlayışına eleştiriler getirmiş, dönemin Türkiye Cumhurbaşkanı Abdullah Gül'ün ve pek çok Alman siyasetçisinin yer aldığı protokolde, Pamuk'un sözleri uluslararası basında Türkiye'ye dair olumsuz bir imaj yaratmıştır (Radikal, 2008). Ancak tıpkı ticari markalar gibi ulusların imajları yeniden konumlandırılabilir, hedefli kültür politikalarıyla değiştirilebilir. Bu amaçla Kültür ve Turizm Bakanlığı'nın da desteklediği Uluslararası İstanbul Edebiyat ve Şiir Festivali'nin kurucu direktörü Adnan Özer, festival hakkında yaptığı bir konuşmada bu etkinliklerle aslında kamu diplomasisi faaliyeti yürüttüklerini belirtmiştir (Anadolu Ajansı, 2017).

2016 yılından bu yana düzenlenmekte olan Uluslararası Nilüfer Şiir Festivali, Uluslararası İstanbul Edebiyat ve Şiir Festivali gibi programlar, yabancı ülkeden 16 ABD'nin yumuşak güç sıralamasında kültür faaliyetleri ile birinci sırada yer alması kültürel faaliyetlere ayırdığı bütçeden, gerçekleştirilen faaliyetlerden görülebilir. Bkz: McClory, 2017; 2018; 2019. 


\section{arts}

gelen yazar ve şairlere Türkiye kültürünü tanıma fırsatı sunarak, pek çok tarihi ve doğal güzelliklerin olduğu yerleri görme şansı da vermektedir. Yine, yakın zamanda gerçekleştirilen, Türkiye tarafından da desteklenen ve Üsküp'te düzenlenen Uluslararası Yahya Kemal Beyatlı Türkçe Şiir Şöleni de yumuşak güç araçlarından biri olarak değerlendirilebilir. Türkiye'nin bu kültür formları festivalde yer alan katılımcılar sayesinde vatandaşı olduğu ülkeye aktarılarak yumuşak güç aracı kullanılır. Bu tarz programlara fonlar sağlamak, izin vermek büyük ölçüde devletlerin diplomasi anlayışına bağlıdır.

Kültürel alt yapısı görece daha zayıf olan ülkelerde performanslarını sergilemek isteyen sanatçılar veya aktörler kendi ülkelerinin diplomatik misyonuna büyük ölçüde bağımlıdır (Pajtinka, 2014, s. 103). Ancak Türkiye bu anlamda yatıımları genişleterek kendi imaj ve itibarını yabancı halklara ulaştırabilme potansiyeline sahiptir. Çünkü Türkçe metinlerin yurtdışında karşıık bulması, çevrilmesi Türkiye kültürünü, Türkiye'de demokrasive insan hakları anlayışını merak konusu haline getirmiştir. Orhan Pamuk'un Nobel Edebiyat Ödülü alması da yurtdışında, pek çok ülkede Türkçe edebiyatı merak konusu kılmış ve böylece diğer Türkçe metinlerin yabancı dillere çevrilme talebini ortaya çıkmışıı.

Ancak bu tarz etkinlikler Türkiye basınına çok fazla konu olamamaktadır. Bu edebiyatın politika karşısında göreceli, önemsiz ve marijinalleştirilmiş bakış açısından ileri gelir. Festivale katılan şair ve yazarlar mesajların alıcı ve verici konumunda olduğundan edebiyat aracılığıyla gerçekleştirilen faaliyetler bir ulusa ve onun kültürüne dair klişeleri yıkabilme gücüne sahiptir. Katılımcılara bir kültürü uzak bir yerden görmek yerine doğrudan temasla görme ve gördüklerini aktarma şansı sunar. Kamu diplomasisinde ilişki inşasını ve diyalojik modeli sağlayabilecek edebiyat ve edebiyat araçları ulusların kendilerini konumlandırmasında önemli bir role sahiptir. Ancak süreklilik arz etmesi birincil ihtiyaçtır. Yalnızca sürekli ve hedefli kültür politikaları aracılığıyla yumuşak gücün faydaları ve sonuçları elde edilebilir.

\section{SONUÇ}

Yeni toplum düzeninde küreselleşme aktörlerinin çeşitlenmesi, çok farklı sosyal grupların ve ağın ortaya çıkması eski araçlarla yeni hedeflere ulaşılamayacağını göstermiştir. Ekonomik ve toplumsal değişimler, yaşanan teknolojik gelişmeler artık sert güç uygulamalarının (askeri ve ekonomik güç) karşılıklı müzakere ve belirlenen 
hedeflere ulaşmak için yeterli olmadığını göstermektedir. Soğuk Savaş döneminde uygulanmaya başlanan ve geleneksel diplomasiden ayrışan kamu diplomasisi, ser† güce başvurmadan elindeki değerlerle (kültür, sahip olunan cazibe ve saire), küresel arenada olumsuz algı yaratmadan, fikir ve eylemlerde müzakereye başvurarak sağduyuyu ön plana çıkaran, hedef aktörü tutum değişikliğine sevk eden bir işlev görür. Yumuşak güç kullanılarak gerçekleştirilen kamu diplomasisi, başka ulusları ve halkları tutum değişikliğine yöneltme işini düşünce düzeyinde başlatarak gerçekleştirir. Yumuşak güç, bu anlamıyla küresel aktörler için önemli bir işleve sahip olduğundan bugün en çok başvurulan kaynaklardan biridir.

Yumuşak güçle alakalı olarak yapılan araştırmalarda kültürel faaliyetlerin etkili olduğu, Türkiye'nin bu anlamda politikaları hayata geçirmesi gecikmeli olsa da son yıllarda bir politika değişikliğine giderek bu alanı öncelikli alanlardan biri haline getirdiği görülmektedir. Kültürel faaliyetlere verilen önemin yeterli olduğunu söyleyemesek de sahip olunan kültür, potansiyel olarak üzerinde durulabilir, dış politika hedefleri arasında birincil sıralarda yer alabilir bir konumdadır. Türkiye'nin bu anlamda yapacağı yatıımlar, ülke itibar ve imajını güçlendirebilir. Güçlü bir kültürel geleneğe sahip olan Türkiye bunu kullanmayı hedefleri arasına yerleştirdiğinde daha kalıcı ve güçlü diplomatik ilişkiler gerçekleştirebilir. Kültür değerleri arasında yer alan Türkçe edebiyat bu anlamda başat bir rol üstlenebilir. Diğer yandan edebiyatın bireysel olandan başlayarak toplumsal alana kayması ve Türkçe edebiyatın zenginliği önemli birer durum olarak karşımızda durmaktadır. Edebiyat aracılığıyla yürütülecek kamu diplomasisi faaliyetleri olarak edebiyat festivalleri, bir bütünsellik arz etmesi açısından; yazar ve şairlerle ortaklaşa gerçekleştirilebilecek stratejik planlar, çeviri faaliyetlerine yönelik tutumlar genişletilip büyütülürse Türkiye sahip olduğu önemli bir gücü kullanabilmiş hale gelir.

Türkiye'nin etkili bir dış politika gerçekleştirmesi ve kamu diplomasisi faaliyetleri ellerindeki mevcut kaynakları nasıl kullanabileceği, gelecekteki ilişki inşası ve imajı için önemlidir. Edebiyattan sinemaya, sanattan medyaya, sivil toplum kuruluşlarından akademiye çeşitlilik gösterebilecek faaliyetlerin bir bütün olarak ele alınıp uygulanmaya başlanması tüm bu faaliyetlerin aktörlerinin katıımıyla mümkün olabilir. Tanımı gereği kamu diplomasisi yalnızca devlet kurumlarının üstlenilmesiyle yapılmadığından sivil toplum kuruluşlarından bağımsız kuruluşlara ya da üniversitelere değin çeşitli aktörlere büyük görev düşmektedir. Kamu kurumları ve sivil toplumun ortaklaşa yapacağı faaliyetlerden biri olarak edebiyatı kamu 


\section{arts}

diplomasisi ile ilişkilendirebilir ve belirlenen hedeflere ulaştırabilecek bir araç olarak görebiliriz. Edebiyatın ötekiye dair klişeleri yıkma, şeylerin nasıl meydana geldiğini merak konusu kılma, düşünce ve davranışları yeniden düzenleme gücü kamu diplomasisi faaliyetlerini kolaylaştırabilir, kalıcı fikir ve davranış oluşturabilir. Bu anlamıyla etkili bir dış politika gerçekleştirmek, hedeflere ulaşmak için edebiyatı da stratejik planlar içerisine yerleştirmek kamu diplomasisi için, özellikle Türkiye için önemli olarak değerlendirilebilir.

\section{KAYNAKÇA}

Anadolu Ajansı (2017, 3 Ekim). Uluslararası İstanbul Şiir ve Edebiyat Festivali' başladı. https://www.aa.com.tr/tr/kultur-sanat/uluslararasi-istanbul-siir-ve-edebiyatfestivali-basladi/926223 Erişim tarihi: 15 Kasım 2020

Belanger, L. (1999). Redefining cultural diplomacy: Cultural security and foreign policy in Canada. Political Psychology, 20 (4), 677-699.

Berridge, G. R. (2001). Machiavelli: human nature, good faith, and diplomacy. Review of International Studies, 27 (4), 539-556.

Bo, L. M. (2018). Writing Diplomacy: Translation, Politics and Literary Culture in the Transpacific Cold War (Yayımlanmamış Doktora Tezi). Columbia Üniversitesi, New York.

Bora, T. (2021). Hasan Ali Yücel. İstanbul: Illetişim.

Castells, M. (2008). The new public sphere: Global civil society, communication networks, and global governance. The Annals of the American Academy of Political and Social Science, 616(1), 78-93.

Clarke, D. (2016). Theorising the role of cultural products in cultural diplomacy from a cultural studies perspective. International journal of cultural policy, 22 (2), 147-163.

Coombs, W.T., \& Holladay, S. J. (2010).PR strategy and application: Managing influence. United Kingdom: Wiley-Blackwell.

Cowan, G., \& Arsenault, A. (2008). Moving from monologue to dialogue to collaboration: The three layers of public diplomacy. The annals of the American academy of political and social science, 616(1), 10-30. DOI: 10.17680/akademia. 
v4i1.5000080313

Fatima, N., \& Khan, Z. A. (2018). Soft Power and Cultural Diplomacy as Counter-Terrorism Measure in Contemporary International Politics. Global Social Sciences Review, 3(2), 1-20.

Felski, R. (2013). Edebiyat Ne Işe Yarar?. (Çev. E. Ayhan). İstanbul: Metis.

Filstrup, J. M. (1976). Franklin book programs/Tehran. International Library Review, 8(4), 431-450.

Financial Times (2017). How J. K. Rowling Built a 25 billion dollar business. https://www.ft.com/content/a24a70a6-55a9-1 1e7-9fed-c19e2700005f Erişim tarihi: 25 Nisan 2021

Gilboa, E. (2006). Public Diplomacy: The Missing Component in Israel's Foreign Policy. Israel Affairs, 12(4), 715-747.

Haddadian-Moghaddam, E. (2016). The Cultural Cold War and the Circulation of World Literature: Insights from Franklin Book Programs in Tehran. Journal of World Literature, 1 (3), 371-390.

Herman, E. S. \& Chomsky, N. (2012). Rızanın Imalatı: Kitle Medyasının Ekonomi Politiği. (Çev. E. Abadoğlu). İstanbul: BGST.

Hobsbawm, E. (2006). Kısa 20. Yüzyıl 1914-1991: Aşırılıklar Çağı. (Çev. Y. Aloğan). İstanbul: Everest.

Hobsbawm, E. (2008). Küreselleşme, Demokrasive Terörizm. (Çev. O. Akınhay). İstanbul: Agora.

Holden, J., Briggs, R., Jones, S., \& Bound, K. (2007). Cultural Diplomacy. London: Demos.

İskit, T. (2007). Diplomasi: tarihi, teorisi, kurumları ve uygulaması. İstanbul: Bilgi Üniversitesi.

Kalın, İ. (2011). Soft power and public diplomacy in Turkey. Perceptions: Journal of International Affairs, 16(3), 5-23.

Kınlı, O. (2006). Osmanlı'da Modernleşme ve Diplomasi. Ankara: İmge.

L'Etang, J. (2009). Public relations and diplomacy in a globalized world: An issue of public communication. American Behavioral Scientist, 53(4), 607-626. 


\section{arts}

McClory, J. (2017). The Soft Power 30: A global ranking of soft power. https://softpower30.com/wp-content/uploads/2018/07/The_Soft_Power_30_ Report_2017-1.pdf Erişim tarihi: 15 Ocak 2021

McClory, J. (2018). The Soft Power 30: A global ranking of soft power. https:// softpower30.com/wp-content/uploads/2018/07/The-Soft-Power-30-Report-2018. pdf Erişim tarihi: 15 Ocak 2021

McClory, J. (2019). The Soft Power 30: A global ranking of soft power. https:// softpower30.com/wp-content/uploads/2019/10/The-Soft-Power-30-Report-2019-1. pdf Erişim tarihi: 15 Ocak 2021

Melissen, J. (Ed.). (2005). The new public diplomacy. New York: Palgrave Macmillan.

Mitchell, J. M. (2015). International Cultural Relations. London: Routledge.

Nawotka, E. (2013, 23 Ağustos). What Role Can Literature Play in Cultural Diplomacy? Publishing Perspectives. https://publishingperspectives.com/2013/08/ what-role-can-literature-play-in-cultural-diplomacy/ Erişim tarihi: 15 Kasım 2020

Nicolson, H. (1963) Diplomacy. London: Oxford University.

Nye, Jr. J.S. (2008). Public Diplomacy and Soft Power. The annals of the American academy of political and social science, 616(1), 94-109.

Öymen, O. (2003). Silahsız Savaş: Bir Mücadele Sanatı Olarak Diplomasi. İstanbul: Remzi.

Özkan, A. (2015). Strategic Practices Of Public Diplomacy Policies In Educational Field And Turkey's Potential For Cultural Diplomacy. Erciyes Illetişim Dergisi, 4(1), 2-12.

Pajtinka, E. (2014). Cultural diplomacy in theory and practice of contemporary international relations. Politické vedy, 17(4), 95-108.

Pasternak, B. (2014). Doktor Jivago. (Çev. H. Arslan). İstanbul: Yapı Kredi.

Purtaş, F. (2013). Türk dış politikasının yükselen değeri: Kültürel diplomasi. Gazi Akademik Bakış, (13), 1-14.

Radikal (2008, 14 Ekim). Frankfurt Kitap Fuarı açıldı. http://www.radikal.com. tr/kultur/frankfurt-kitap-fuari-acildi-903400/ Erişim tarihi: 06 Kasım 2020 
Robbins, L, S. (2007). Publishing American Values: The Franklin Book Programs as Cold War Cultural Diplomacy. Library Trends 55(3), 638-650.

Sağlam, M. Y. (2014). Dünya edebiyatına uzanan yolda bir Türk romancı: Orhan Kemal. Erdem, (67), 87-104. DOI: 10.32704/erdem.537456

Sak, E. ve Adilbekova, K. (2015). Rusya Ve Kültürel Diplomasisi. Barış Araştırmaları ve Çatışma Çözümleri Dergisi, 3(1), 42-84.

Sancar, G. A. (2012). Kamu Diplomasisi ve Uluslararası Halkla Illişkiler. İstanbul: Beta.

Schneider, C. P. (2006). Cultural diplomacy: Hard to define, but you'd know it if you saw it. The Brown journal of world affairs, 13(1), 191-203.

Signitzer, B. \& Wamser, C. (2006). Public diplomacy: A specific governmental public relations function. C. Botan \& V. Hazelton (Ed.). Public relations theory II, (s. 435-464). London: Routledge.

South China Morning Post (2019). Pen is mightier than the sword: Novelists help China's soft power push in Latin America. https://www.scmp.com/news/ china/diplomacy-defence/article/1804521/pen-mightier-sword-novelists-helpchinas-soft-power Erişim tarihi: 06 Ekim 2019

Şüküran, M. Ö. (2019). Umut için bir barınak: edebiyat. Varlık Dergisi, 1340, 13-16.

Tuch, H. N. (1990). Communicating with the World: US public diplomacy overseas. New York: St. Martin's.

Tuncer, H. (1991). Eski ve Yeni Diplomasi. Ankara: Ümit.

Uygur, N. (2003). Kültür Kuramı. İstanbul: Yapı Kredi.

Ünal, U. (2019). International Publishing Practices Within Turkey's Cultural Diplomacy. Gümüşhane Üniversitesi Illetişim Fakültesi Elektronik Dergisi, 7(2), 609-645.

Ünalmış, A. N. (2019). Yumuşak Gücün Tesis Edilmesinde Kültürel Diplomasinin Önemi ve Bir Uygulayıcı Olarak Yunus Emre Enstitüsü. Bilig-Türk Dünyası Sosyal Bilimler Dergisi, (91), 137-159.

Yağmurlu, A. (2007). Halkla İlişkiler Yöntemi Olarak Kamu Diplomasisi. Illetişim: Araştırmaları, 5(1), 9-38. 
Yağmurlu, A. (2019). Kültürel Diplomasi: Kuram ve Pratikteki Çerçevesi. Selçuk İletişim, 12(2), 1210-1238.

Yıldırım, G. (2015a). Uluslararası Halkla illişkiler Perspektifinden Kamu Diplomasisi. İstanbul: Beta.

Yıldırım, G. (2015b). Türkiye Kamu Diplomasisi Koordinatörlüğü'nün Faaliyetlerinin Kültürel Diplomasi Bağlamında İncelenmesi. Karadeniz Teknik Üniversitesi Iletişim Araştırmaları Dergisi, 5(1), 2-24.

Yıldırım, M. Ö. (2020). Kara Zamanlardan Çıkış Koridoru Olarak Edebiyat. Yeni E, (47), 68-73. 